amount of experimental biological work has been carried out. It was suggested that it might be possible to inject the radio-sodium into the tissues, apparently with the view of obtaining its local action upon malignant growths. How the localisation is to be effected will, we think, be rather a problem. A further point is that the short half-life period is not necessarily by any means an advantage from the therapeutic point of view. One of the certain facts which have resulted from the scientific study of radiation therapy is that uniform and carefully adjusted dosage is essential to success. The new product-radio-sodium-produces a form of radiation which is rapidly diminishing in amount; constancy of radiation, therefore, cannot be expected. It is certainly by no means the case that an initial heavy dose of radiation which rapidly decreases will have the same biological effect as the same total dose provided by a smaller constant source acting for a longer time. From the physico-chemical point of view, Prof. Lawrence's work is of the deepest interest, but to mention therapeutic possibilities at this early stage seems to us decidedly premature.

\section{Red Kafirs of Nuristan}

IT is anticipated that further light will be thrown on the much-disputed origin of the Bashgali, or 'Red Kafirs' of Afghanistan, by recent investigations of their language and customs by Dr. George Morgenstierne, of the Göteborg High School, Sweden. In the meantime, The Times correspondent at Simla reports in the issue of August 17 that a German botanical expedition, which has worked its way through the Hindu Kush to the Chitral, has come into contact with the Red Kafirs among other strange tribes of Nuristan. The Red Kafirs-so-called to distinguish them from the Black Kafirs, whom some ethnologists regard as having negro affiliations-are sometimes credited with an origin which legend traces to Arabia, while on another view it has been suggested that they are descendants of the soldiers of Alexander. The most probable theory is that both racially and culturally they preserve a strain of the same stock as the Aryan invaders of India. Although they have been converted to Islam, they retain a number of pagan customs, in which some would see traces of ancient Greece. It is probable, however, that the resemblance is no more than generic, and that the strange customs reported of them are a debased survival of beliefs of the primitive Arya. Thus it is said that although they believe in one chief god, they also recognise forty or fifty other deities, to whom sacrifices are offered on high places, while the dead are placed in sacred groves. One of the most interesting features of their customs is a song and dance ritual in connexion with a central altar. Dead heroes are commemorated by wooden equestrian statues, which are sometimes accompanied by figures of an attendant and the hero's wives seated behind on chairs. The general character of these statues and their technique have been made the basis of a suggested connexion with the statues of Easter Island, and thought to point to one possible source of the 'Aryan' strain which some would see in Polynesia.

\section{Restoration at Avebury}

OPERATIONS for the exploration and restoration of the avenue leading from Overton Hill to Avebury, which were begun by Mr. Alexander Keiller last year, have been resumed. It is expected that all the surviving stones of the avenue will shortly have been placed in their original positions. The recent work has yielded information as to the original plan and method of construction additional to that obtained last year. Six stones, it is stated in a report in The Times of August 24, have been re-erected this year, including two of the largest megaliths known in the whole of the avenue, and the only two remaining stoneholes in the section have been identified; and at the time of writing two stones were still to receive attention. Of these, No. 9 is the only one which has never fallen. Advantage will be taken of the concreting, which will make it safe for future generations, to examine the method of packing followed when it was erected originally. The companion stone, No. 10, re-erected by Mrs. M. E. Cunnington in 1912, was shown by last year's examination to have been replaced some distance from its original position, as well as back to front and upside down. It will be placed in its correct position in its proper stone-hole, which has recently been discovered. In the next section, excavations are being undertaken on the sites of the stones between the north-western limits of last year's operations and the entrance to the circle. Here evidence has been found to show that at least two of the stone posts were broken up on the spot and without the use of fire. No. 39, partially uncovered in the laying of a pipe-line in 1913, and No. 40 have now been completely excavated, and will be re-erected shortly.

\section{Further Discoveries at Colchester}

LATER excavation of the remains of the remarkable wall discovered on the Romano-British site on Sheepen Farm at Colchester (see Nature, August 17, p. 251) have served only to strengthen early impres. sions of its singular character. It has been found to run in an east-west direction for a distance of approximately $352 \mathrm{ft}$. At the eastern end, the possibility of further examination comes to an end at Sheepen Lane, so that it cannot be stated how far, if at all, it extended in this direction. At the western extremity, after a somewhat sinuous course, the wall turns in a right-angled bend to run northward, the construction continuing to be identical in form. The northern corner of what was evidently a large enclosure was located on this western side at a distance of $291 \mathrm{ft}$. from the southern turn. The course of the northern face is now being traced. Vestiges of cross walls, one running east and west, the other north and south, have been found at a point situated approximately $150 \mathrm{ft}$. east of the west wall. Of these, the former is the more substantial, its foundations having a breadth of $4 \mathrm{ft}$. 6 in., while those of the latter are only $2 \mathrm{ft} .6 \mathrm{in}$. wide. Further excavation showed these to be part of the walls of a Romano-Celtic temple, of which the enclosure was the temenos. The walls of the temple have now been completely traced (The Times, August 28). 